\title{
UM QUADRO NENHUM
}

RAMOS, Maria Beatriz Del Peloso

Minha mãe tinha uma palidez espelhada em olhos mergulhados num vazio profundo, que transitava entre ausência e serenidade. Imersa em longos momentos de quietude, era envolvida por uma atmosfera desconhecida que a levava para distâncias encobertas de tristeza, como se estivesse perdida.

Vagava num espaço disperso, presa de um tempo impenetrável que a possuía com magnetismo, arrancando-a da realidade e dificultando seu retorno ao cotidiano, embora fosse sempre amparada pelas mãos de alguém da casa.

Incontáveis vezes, sua aflição mansa pairava sobre cenas domésticas com expressão desoladora, e desvencilhando-se, seu espírito saía à solta, voando pelo espaço, num devaneio silencioso feito de sombras que escureciam nosso mundo, mantendo-nos afastados. Era o momento em que sua alma viajava, demoradamente, sem vontade de regresso, tornando-se transparência, evadida na fluidez vertiginosa de um vôo assustado de pássaro pequeno em debandada fuga.

Em sua inconsciente rotina, vestia o casaco comprido, sentava-se na cadeira da sala, com a bolsa de tecido floral no colo, e lá permanecia quieta, até anoitecer. Alguém perguntava-lhe algo, ela respondia que já estava pronta, levantava-se, segurando a bolsa, parava diante da porta, olhava-a fixamente, mas não saía.

Minha mãe nunca conseguiu sair de casa. Entre a porta e a rua havia um espaço abissal que impedia seus passos.

Certa manhã, não a vi na sala esperando o emaranhado do delírio chegar, e levá-la para longe. Acordou cedo, costurou meu uniforme sem botão, pendurou-o no armário, engraxou meu par de sapatos e, dentro, colocou um bilhete. Vestiu o casaco, pegou a bolsa florida, abriu a porta e saiu. Minha mãe foi embora e eu nunca mais a vi.

Prisioneira liberta de sua demência, ainda assim, deixou-me um pedaço de papel, coberto por uma escrita fragilizada que venho lendo vida afora, tentando entender o desastre que a dominou, Jangada | nr. 10, jul/dez, 2017 | ISSN 2317-4722 - 145 |P á g in a 
levando-a envolta numa aragem que, rispidamente, transformou-se em ventania, e desfez sua vida em fios esgarçados.

Penso com que interdição ela teceu as linhas do bilhete, fiapos destruídos de seu íntimo, resto da fagulha que iluminou seu breve fragmento de lucidez, de onde conseguiu extrair, apesar de toda estranheza, um sopro poético.

No silenciamento, ela evocou o mais gritante apelo sufocando minhas lembranças impregnadas, desde cedo, de contradição como se estivessem presas numa gaiola pequena, guardada em caixa estreita e coberta pela escuridão de suas palavras.

Todas as vezes que releio, e em vão, tento unir os pedaços ausentes de sua imagem, num esforço para reconhecê-la, sou, também, como ela, pássaro em arrebatado voo cego, porque mortal.

Minha mãe, com a voz impedida de ecoar, e sofrendo a indigência da exclusão, trouxe à cena sua fala recalcada, e assim se despediu:

- Saí porque armava chuva. O céu escuro e baixo oprimia meu coração, mas as flores precisavam de água, e vou regá-las em minha viagem. Quanto tempo dediquei a este buquê que carrego, no colo, inertes flores de tecido, sem necessidade de água e luz? Desbotadas, enfeitam minha loucura; cúmplices, esperaram-me sem pressa, enquanto eu me afastei das flores vivas, descuidadas pelo abandono. Entre as de pano e as vivas, escolho as que podem me acompanhar agora, atadas em minhas mãos, feitas com linhas costuradas no meu devaneio, sem me mostrar saída; elas me levam junto, acompanham os alinhavos que cobrem o desenho das pétalas, seguem ponto por ponto, contornam-se, entrelaçam-se e começam de novo, num caminho só de ida, sem fim. De todas as flores que plantei, nenhuma sobreviveu, porque fui incapaz de entender onde começam e terminam, assim como eu, criatura quebrada por um tempo enfermo, seguindo para um quando nenhum. Agora, vou lhes dar um pouco de água. Que a chuva venha logo! 